\title{
Reply to comments on: Fundamental aspects and technological implications of the solubility concept for the prediction of running properties
}

\author{
Citation for published version (APA): \\ Klostermann, J. A., \& Landheer, D. (1981). Reply to comments on: Fundamental aspects and technological \\ implications of the solubility concept for the prediction of running properties. Wear, 66, 125-129. \\ https://doi.org/10.1016/0043-1648(81)90039-9
}

DOI:

10.1016/0043-1648(81)90039-9

Document status and date:

Published: 01/01/1981

\section{Document Version:}

Publisher's PDF, also known as Version of Record (includes final page, issue and volume numbers)

\section{Please check the document version of this publication:}

- A submitted manuscript is the version of the article upon submission and before peer-review. There can be important differences between the submitted version and the official published version of record. People interested in the research are advised to contact the author for the final version of the publication, or visit the DOI to the publisher's website.

- The final author version and the galley proof are versions of the publication after peer review.

- The final published version features the final layout of the paper including the volume, issue and page numbers.

Link to publication

\footnotetext{
General rights

- You may freely distribute the URL identifying the publication in the public portal. follow below link for the End User Agreement:

www.tue.nl/taverne

Take down policy

If you believe that this document breaches copyright please contact us at:

openaccess@tue.nl

providing details and we will investigate your claim.
}

Copyright and moral rights for the publications made accessible in the public portal are retained by the authors and/or other copyright owners and it is a condition of accessing publications that users recognise and abide by the legal requirements associated with these rights.

- Users may download and print one copy of any publication from the public portal for the purpose of private study or research.

- You may not further distribute the material or use it for any profit-making activity or commercial gain

If the publication is distributed under the terms of Article $25 \mathrm{fa}$ of the Dutch Copyright Act, indicated by the "Taverne" license above, please 
3 A. W. J. de Gee, A. Begelinger and G. H. G. Vaessen, The applicability of the solubility concept, Proc., Inst. Mech. Eng., London, 182(3A) (1967-1968) 381 - 382.

4 A. W. J. de Gee, Friction and wear as related to composition, structure and properties of metals, Int. Metall. Rev., 239(2) (1979) 57 - 67.

(Received October 16, 1980)

A. J. W. DE GEE

Metaalinstituut TNO,

P.O. Box 541,

7500 AM Apeldoorn, The Netherlands

Reply to comments on "Fundamental aspects and technological implications of the solubility concept for the prediction of running properties"

Contaminating films can have a substantial effect on the sliding behaviour of metallic couples, the actual influence depending on the type and thickness of the particular film involved. We thank Dr. de Gee for stressing this point.

From ref. 1 at least three regimes of film influence on dry sliding may be suggested, i.e. (1) regime $A$ where the contaminating film has a negligible effect on metallic interaction, (2) regime $B$ where the contaminating film has a mitigating effect on metallic interaction and (3) regime $C$ where the contaminating film has a positive effect on metal transfer. In addition a regime $\mathrm{D}$ may be discerned for certain material combinations and experimental conditions in which the contaminating layers strongly reduce wear [2].

Regime A occurs if no or hardly any film can be formed because of the purity of the environment (e.g. ultrahigh vacuum) or if potential thin films are ruptured at the real contacts during sliding because of insufficient mechanical support by a weak substrate (e.g. silver on pure iron in an inert gas containing less than $0.5 \mathrm{ppm} \mathrm{O}_{2}[1]$ ). In this regime direct metallic contact between the sliding members prevails over nearly the whole real contact area, usually resulting in metal transfer.

Regime B occurs at slightly higher oxygen pressures, e.g. $50-100 \mathrm{ppm}$ $\mathrm{O}_{2}$ in argon for de Gee's tests with $\mathrm{Au}-\mathrm{Ag}$ alloys against steel [3] . Very thin iron oxides are supposed to shield the surfaces partially from metallic interaction. The remaining interaction causes a behaviour as predicted by the "classical" solubility concept. This behaviour seems to agree rather well with common engineering practice and reasons can be found to explain why regime B prevails in contacts not heavily loaded.

For regime $\mathrm{C}$, somewhat higher oxygen pressures are required (over $1000 \mathrm{ppm} \mathrm{O}_{2}$ in argon for silver on steel [4]). The films formed now seem to act to a certain extent independently of the metallic substrate (at least, the applicability of the solubility concept is excluded) and favour the occurrence of transfer.

Although the experiments and calculations in ref. 5 concern regime A, we feel that the model proposed will be applicable to regime $B$ as well. Further, because the low accessibility of running surfaces to oxygen in 


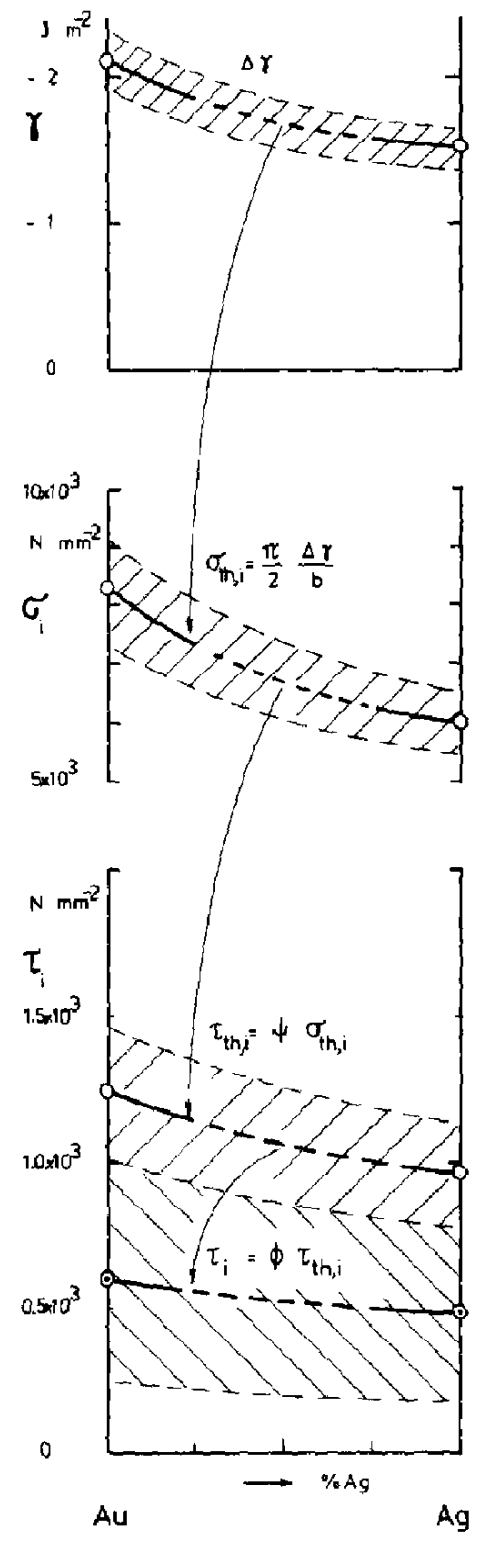

(a)



(b)

Fig. 1. (a) Interfacial shear strength $\tau_{\text {th }, j}$ of the atomic contacts between Au-Ag alloys and iron as a function of the alloy composition, and indication of the derivation of $\tau_{i}$ from the work of adhesion $\Delta \gamma$. (The shaded areas suggest the possible spread of the quantities involved.) (b) Values of the shear strengths $\tau_{\text {th }}$ and $\tau^{*}$ of running surface materials for the atomic and real contacts respectively.

lubricated systems makes such systems comparable with regime $B$, the model will also be relevant to engineering situations. 
The value of the junction strength ratio $T$ is taken as a criterion for the possibility of metal transfer where

$$
T=\frac{\text { shear strength of the interface of a junction }}{\text { shear strength of the adjacent junction material }}
$$
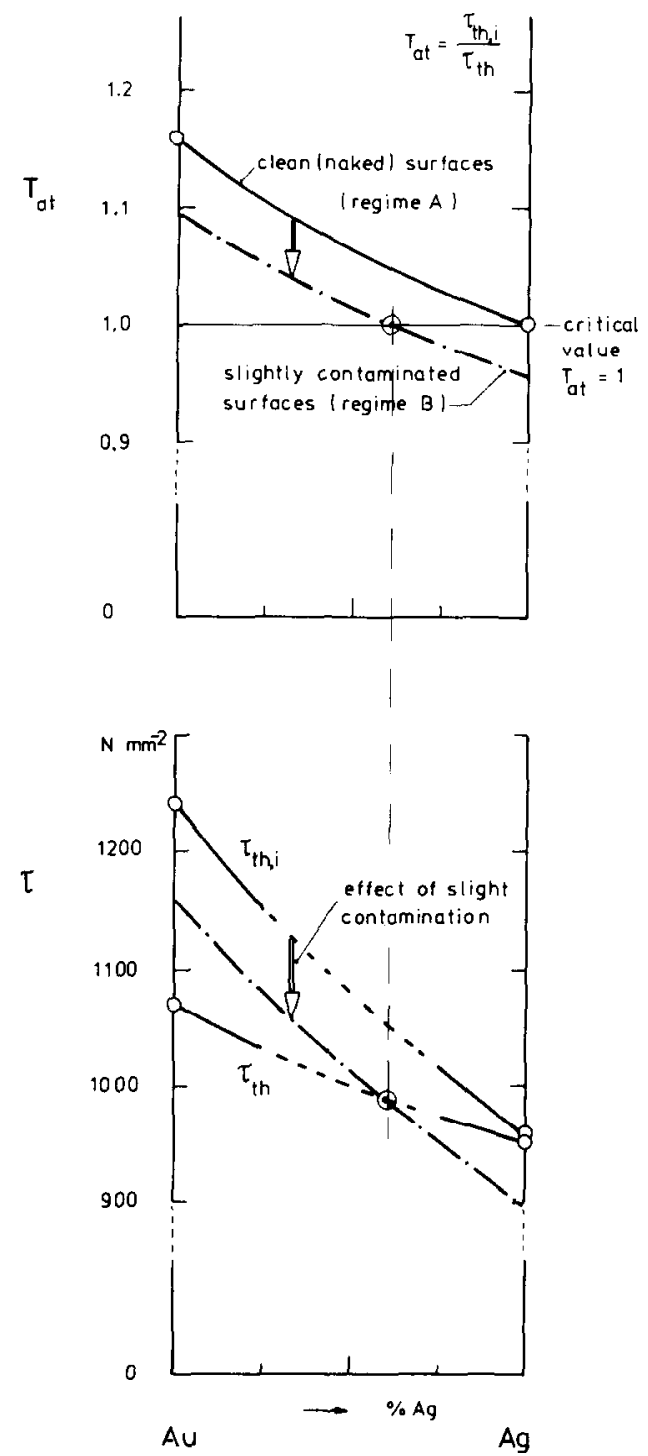

Fig. 2. Comparison of the interfacial and weakest running surface material shear strength values for atomic contacts between $\Lambda u-A g$ alloys and iron, and the ratio $T$ of thesc quantities. The reductions in $\tau_{t h, i}$ and $T_{\text {at }}$ caused by very slight surface contamination (regime $B$ instead of regime $A$ ) are indicated by the arrows. 
$T$ can be applied to atomic contacts $\left(T_{\mathrm{at}}=\tau_{\text {th }, \mathrm{i}} / \tau_{\text {th }}\right)$ and to real contacts $\left(T_{\mathrm{r}}=\tau_{\mathrm{i}} / \tau^{*}\right)$. When both $T_{\mathrm{r}}$ and $T_{\mathrm{at}}$ are greater than or less than unity a strong transfer tendency or no transfer respectively may be expected, while for $T_{\mathrm{at}}>1$ and $T_{\mathrm{r}}<1$ an intermediate behaviour seems probable. Figure 1 depicts schematically the derivation of the interfacial and running surface shear strength values for uncontaminated contact between $\mathrm{Au}-\mathrm{Ag}$ alloys and iron or steel, and Fig. 2 shows $T_{\mathrm{at}}$ as a function of the alloy composition for the weakest contact member. Obviously for all compositions transfer is predicted, in accordance with our experimental findings. If slight contamination of one or both surfaces causes a reduction in the interfacial strength $T_{\mathrm{at}}$ will be reduced in regime $\mathrm{B}$ with respect to regime $\mathrm{A}$ as depicted by the arrow in Fig. 2, and consequently transfer becomes probable up to a critical silver content only, as found experimentally by de Gee. In view of our approach the fact that the critical composition in ref. 3 equals that for vanishing iron solubility might be more coincidental than fundamental, the more so as the solubility of the alloy in the iron is not relevant. This point does not alter the fact that mutually soluble couples generally have a stronger tendency to metal transfer than do insoluble couples.

1 A. W. J. de Gee, A. Begelinger and G. H. G. Vaessen, The applicability of the solubility concept, Proc., Inst. Mech. Eng., London, 182(3A) (1967 - 1968) 381 - 382.

$2 \mathrm{~J}$. K. Lancaster, The formation of surface films at the transition between mild and severe metallic wear, Proc. R. Soc. London, Ser. A, 273 (1963) 466 - 483.

3 A. W. J. de Gee, The friction of gold-silver alloys against steel, Wear, 8 (1965) 121 132.

4 A. Begelinger and A. W. J. de Gee, Sliding characteristics of silver against iron as influenced by oxygen concentration, ASLE Trans., 10 (1967) 124 - 133.

5 D. Landheer, A. J. G. Dackus and J. A. Klostermann, Fundamental aspects and technological implications of the solubility concept for the prediction of running properties, Wear, 62(2) (1980) $255 \cdot 286$.

(Received December 27, 1980)

D. LANDHEER and J. A. KLOSTERMANN Technische Hogeschool Eindhoven, Den Dolech 2, Postbus 513, $5600 \mathrm{MB}$ Eindhoven, The Netherlands 